\title{
TEACHING ENGLISH LOCATIVE PREPOSITIONS: A COGNITIVE PERSPECTIVE
}

\section{INTRODUCTION}

One area that has received much attention from cognitive linguistics (CL) researchers (Lakoff 1987; Lindstromberg 1996; Rohlfing 2001; Evans and Tyler 2005) is the semantic nature of English prepositions. They are notoriously hard to learn and frequently subject to negative transfer. In addition, prepositional meanings are commonly extended from the spatial to abstract domains and are, as a consequence, often unpredictable and arbitrary. This suggests that the best way to learn second language (SL) prepositions would be through rote learning. An alternative to the traditional approach, which assumes that prepositions are best learnt by memorizing the individual contexts in which they occur, is the collocation approach, according to which prepositions are best acquired by learning the collocations in which they occur. This approach has several advantages. Research has suggested that people naturally process groups of words as single units or chunks, which has led researchers to argue in favour of frequency-based learning (Mueller 2011.) However, both of these approaches see prepositional meanings as unrelated to each other. A CL-based approach offers an alternative perspective by arguing that the multiple uses of prepositions can be seen as related in systematic ways, implying important pedagogic implications.

This article discusses several pedagogical implications of a CL-based approach and looks at some of the ways in which the theory may be translated into practical consideration. While the majority of studies which discuss the teaching of prepositions from a cognitive perspective focus on the extended uses of prepositions as motivated polysemy networks, the focus here is on the more central uses of the locative prepositions in, on and $a t$. The main reason for this is the realisation that even students with relatively high levels of English still experience difficulty with the fairly basic uses of these locative prepositions, which can largely be attributed to the effects of negative transfer. In an attempt to provide learners with effective strategies to deal with this, a CL-based model of explicit instruction on the use of English locative prepositions has been developed, based on the general conceptual schemas associated with a particular preposition.

The article begins by looking at some key insights from the Common European Framework of Reference for Languages (CEFR) and their relevance for the issues discussed. This is followed by an overview of research related to different aspects of using

* Author's address: Pedagoška fakulteta, Univerza na Primorskem, Cankarjeva 5, 6000 Koper, Slovenia. E-mail: silva.bratoz@pef.upr.si. 
a CL perspective in teaching SL prepositions and a discussion of locative prepositions from a contrastive perspective. Then I present an instructional model for the teaching of the English locative prepositions in, on and at, and discuss the results of a study conducted to observe the learners' response to CL-based instruction. The article ends with a few remarks about limitations and future directions for experimental work on the efficacy of using a CL-based approach for teaching purposes.

\section{A CROSS-LINGUISTIC PERSPECTIVE}

Since its publication in 2001, the CEFR has brought attention to several aspects of second language education which have resulted in important implications for both curricula development and teaching practice. It has been made clear that "the aim of the Framework is not to prescribe or even recommend a particular method, but to present options, inviting you to reflect on your current practice, to take decisions accordingly and to describe what you actually do" (CEFR 2001: Notes for the user). In this spirit, the present paper relies on several insights and ideas promoted by the CEFR ${ }^{1}$. First is the realisation that problems may arise when a particular conceptual field is differently organised in the native (L1) and target languages (L2). This is usually the case with word-meanings where we have partial or inexact correspondence between different languages. An important point raised in the CEFR (idem.: 132) in this context is that it is necessary to establish the seriousness of the mismatch and the extent to which the mastery of the distinction should be attended to.

Another related idea is that the linguistic knowledge a learner has already acquired in his/her mother tongue can be fruitfully exploited for language learning by focusing on the contrasting factors involved. This is related to one of the main aims of the article: to emphasise the benefits of focusing on the cross-linguistic differences between L1 and L2, in an explicit and systematic way. Thirdly, the CEFR lays considerable emphasis on the cultural context in which a language is set, and points out that language is "not only a major aspect of culture, but also a means of access to cultural manifestations" (idem.: 6). In this respect, translation studies, especially the approaches which emphasize how embedded a language is in the culture in which it features, can provide useful insights and contribute to enhancing learners' cross-linguistic and intercultural awareness (cf. Kocbek 2013; Bratož and Kocbek 2013.) This is also a key assumption underlying the cognitive linguistics investigation which is based on the premise that languages are embedded in cultural contexts.

\section{A COGNITIVE APPROACH TO TEACHING PREPOSITIONS}

Several scholars (Littlemore 2009; Evans and Tyler 2005; Niemeier and Archard 2004) have recently dealt with the different ways in which the key claims from the CL

1 Several other European references in the area of language learning and teaching promote the concepts and ideas included in the CEFR, such as the Action Plan 2004-2006 (Pižorn and Brumen 2008). 
framework can be effectively applied to the area of second language acquisition and pedagogy. Littlemore (2009) provides an exhaustive overview of the main tenets of the cognitive linguistics theory and discusses different ways in which they may be relevant for the area of second language learning and teaching. She argues convincingly that by understanding the cognitive processes underlying the learning of a second language, we may be better equipped to develop effective second language teaching (SLT) methods and practices.

The semantics of prepositions has received considerable attention in the pedagogical grammatical framework. Lindstromberg (1996) argues in favour of using Lakoff's (1987) prototype theory for teaching prepositions and adverbs. According to this theory, prepositions are likely to have a small number of related meanings, among which one is usually "prototypical". The prototypical meaning is, more often than not, spatial or physical. In addition, some of the literal meanings of a preposition are extended by metaphor to create another small set of related meanings. Some non-prototypical meanings can be explained by extending their prototypical meaning. One of the examples Lindstromberg (idem.: 232-233) gives is the metaphorical use of the preposition in the expression giving up on somebody (e.g. Don't give up on me), which suggests that viewing the action involved in the situation is a burden: by extension, this is conceptualised as a misfortune for the person involved, which can be visually depicted in the image of physically carrying a burden on one's back.

Evans and Tyler (2005) have examined various aspects of English prepositions from a CL perspective, arguing that a more systematic account of the semantics of English prepositions can have clear benefits for SLT purposes. By focusing on different meanings associated with a particular preposition in a systematic way, such as analysing the semantic network of a preposition, learners are presented with less arbitrariness and irregularity which require memorisation. They propose viewing prepositions on the basis of their association to proto-scenes (highly schematic spatial scenes, or the primary meanings associated with a particular preposition) whereby each proto-scene refers to the primary meaning representation of a particular preposition. Prepositions and their associated uses are thus represented as an organised network of related meanings. The authors present a model of English prepositions in which "the various senses are represented as gestalt like conceptualizations of situations or scenes which are systematically connected, rather than a series of discrete dictionary-type definitions strung together in a list" (idem.: 4).

An attempt at applying a CL perspective to instructed L2 learning has been made by Tyler, Mueller and Ho (2011). The authors carried out an experiment in which the participants were non-native speakers of English, who experienced difficulty with the semantics of the English prepositions to, for and at, despite their otherwise advanced mastery of the language. The participants were subjected to a CL-based instructional intervention which consisted of a teacher-fronted instruction, followed by pair-work activities. The results of the study suggest that the learners were able to make significant progress on their accurate interpretation and use of the targeted prepositions.

There are several other aspects of developing CL-based teaching strategies and materials which are worth investigating further. For example, Tyler, Mueller and Ho 
(idem.: 196) argue that the design of effective CL-based teaching materials should also be informed by the fields of psychology and second language acquisition, especially as regards "the importance of noticing, interestingness, role of pushed input, and explicit instruction followed by communicative tasks".

\section{PREPOSITIONS FROM A CONTRASTIVE PERSPECTIVE}

Languages differ significantly in the way they classify spatial configurations, which is due to the different ways languages categorise space (Rohlfing 2001). These differences are even more pronounced if space is perceived as an abstract entity. Celce-Murcia and Larsen-Freeman (1998) argue that even in relatively closely-related languages there may be a "mismatch" in the way prepositions are used. Let us look at some examples of how the locative preposition in is used in English for some fairly basic spatial relations, and how it matches up with Slovene equivalents ${ }^{2}$.

\begin{tabular}{|c|c|c|}
\hline 1) & $\begin{array}{l}\text { The owner and one of his daughters } \\
\text { lived in the house. }\end{array}$ & $\begin{array}{l}\text { Vhiši je bilo žalostno vzdušje. } \\
\text { (Eng. in the house) }\end{array}$ \\
\hline 2) & My phone's in the car. & $\begin{array}{l}\text { Vavtu je bilo ogromno prtljage. } \\
\text { (Eng. in the car) }\end{array}$ \\
\hline 3) & I knew what was in the bag: cans. & $\begin{array}{l}\text { Obleka je } v \text { torbi zasedla razmeroma malo } \\
\text { prostora. } \\
\text { (Eng. in the bag) }\end{array}$ \\
\hline 4) & $\begin{array}{l}\text { I have about } 20 \text { plants in the garden } \\
\text { right now. }\end{array}$ & $\begin{array}{l}\text { Na vrtu sta pridelala večino zelenjave, ki sta jo } \\
\text { potrebovala. } \\
\text { (Eng. *on the garden) }\end{array}$ \\
\hline 5) & $\begin{array}{l}\text { James is in the fields, working side- } \\
\text { by-side with his father. }\end{array}$ & $\begin{array}{l}\text { Na polju zagleda soseda Poldeta, kako ves } \\
\text { prepoten okopava krompir. } \\
\text { (Eng. *on the field) }\end{array}$ \\
\hline 6) & $\begin{array}{l}\text { Follow the blue star in the sky and } \\
\text { search for the others. }\end{array}$ & $\begin{array}{l}\text { Tudi enega oblačka ni bilo na nebu. } \\
\text { (Eng. *on the sky) }\end{array}$ \\
\hline 7) & $\begin{array}{l}\text { We've got the best universities in } \\
\text { the world. }\end{array}$ & $\begin{array}{l}\text { Nokia } 7200 \text { je najbolj ženski telefon na svetu. } \\
\text { (Eng. }{ }^{*} \text { on the world) }\end{array}$ \\
\hline
\end{tabular}

As we can see from the examples above, the preposition is the same in English and Slovene in examples 1-3, while in examples 4-7 in is translated as on in Slovene. Although these examples refer to fairly basic spatial senses, it is clear that the two sets of examples differ in an important way: 1-3 describe more or less clearly defined three-dimensional spaces, while 4-7 are more abstract and leave some space for interpreting the nature of the space. In addition, the prepositional phrases in the sky and in

2 The English examples are taken from the Corpus of Contemporary American English (http:// corpus.byu.edu/coca/) and the Slovene examples are from the Slovene language corpus Fidaplus (http://www.fidaplus.net/). 
the world in examples 6-7 may be used idiomatically and are therefore often learnt as familiar word patterns or chunks. From a CL perspective, we can say that house, car and bag are all clearly conceptualised as containers in both languages. On the other hand, while field, garden, sky, and world are conceptualised in English as containers, in Slovene they are based on a surface-schema. A question one could ask here is, for instance, whether the conceptual domains field, garden, world, and sky look more like a flat surface and are therefore associated with the preposition on, or a container which means we can go in them.

I would like to argue that this mismatch between the two languages poses major challenges to Slovene learners of English, which frequently results in negative transfer. From an SLT perspective, cross-linguistic differences may produce several effects, both positive and negative. Odlin (1989) points out that negative transfer refers to divergences of norms from the target languages and usually involves production errors $^{3}$. According to Ellis (2003: 72), this is especially the case with adult learners, who have already acquired knowledge of L1 categories and their relationships, and that this knowledge "may guide their creative combination in their L2 interlanguage to variously good or bad effects".

It goes without saying that more examples would need to be analysed in order to draw conclusions about the nature of matching between English and Slovene prepositions. However, one of the things that may be noticed by looking at examples 4-7 above is that there is a degree of systematicity in the translation of the English in into the Slovene on. While it is beyond the scope of this article to give a full theoretical account of the semantics of English and Slovene locative prepositions, I would like to argue that such an analysis would be helpful in identifying the teaching priorities and in developing effective teaching strategies. In her analysis of the radial structure of the preposition on in English and Slovene, Sicherl (2007) concluded that there is high degree of semantic overlap between the two languages, both in the central and extended senses of the preposition. On the basis of these findings, we may predict that Slovene learners of English will have fewer difficulties using this particular preposition. A CLbased approach to teaching prepositions would certainly benefit from such systematic accounts of the radial structures of prepositions in L1 and L2.

\section{A CL-BASED APPROACH TO TEACHING BASIC LOCATIVE PREPOSI- TIONS}

In an attempt to bridge theory and practice, this portion of the paper presents an instructional model for teaching prepositions from a cognitive perspective. It first discusses the difference between a more standard approach to explaining the use of English locative prepositions and a CL-based approach. As we can see below, a CL-based model differs from a standard learner's grammar approach in two sig-

3 He does point out that there are also other ways in which an individual's second language performance may differ from the behaviour of native speakers, including underproduction, overproduction, or misinterpretation (Odlin 1989: 36-37). 
nificant ways. First, standard instruction on the uses of prepositions, as found in most modern learner's grammars, is usually based on general descriptions of the use of prepositions in different concrete situations. For the use of locative prepositions, for example, reference is usually made to particular places, such as a building, country, river, etc. Exceptions and special cases are sometimes added and explained, such as the difference in meaning in the use of the prepositions in or at with reference to buildings (e.g. I'm at the cinema. vs. I'm in the cinema). In addition, explanations are often accompanied by icons or pictures of objects in different relations to each other.

\section{Standard Instruction Approach}

Prepositions of space describe where one person or thing is in relation to another. To express notions of place, English uses the following prepositions:

1. When something is "in" a place, it is inside it. We can also use "in" when we talk about a place as a general area, such as a region or a country.

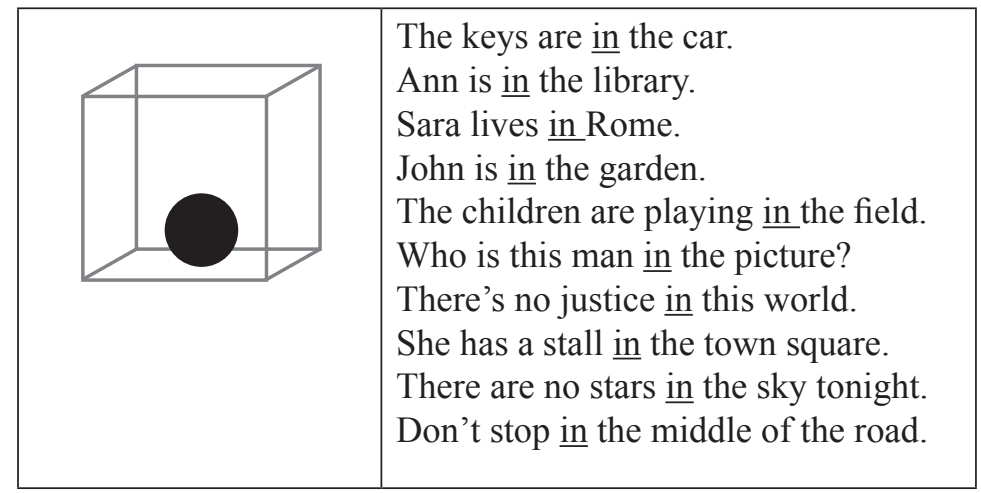

2. When something is "on" a place, it is in contact with a surface. We can also use "on" when we talk about a place in relation to a line, such as a road or a river.

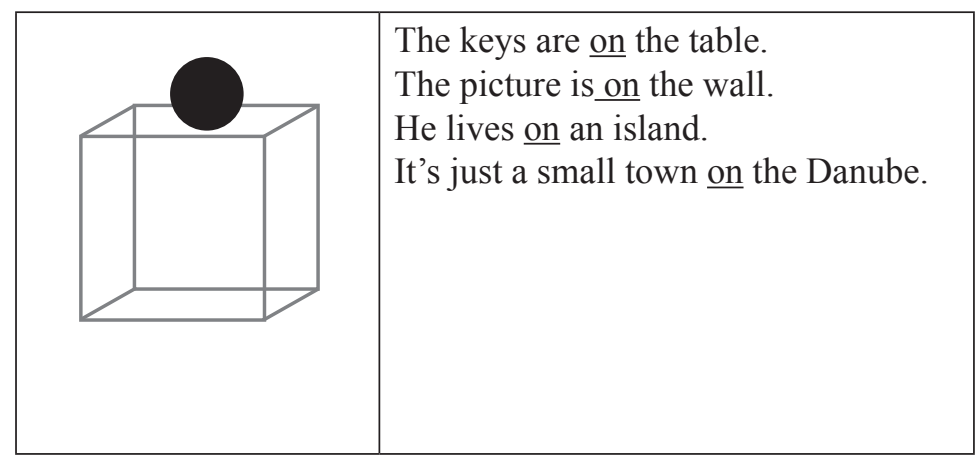


3. We use "at" to talk about a general vicinity.

\begin{tabular}{|l|l|}
\hline at the baker's & at the airport \\
at the office & at the counter \\
at school & at 5 Maryland Street \\
at a party & at the door \\
at a bus stop & at Peter's (house) \\
\hline
\end{tabular}

In addition to the elements above, a CL-based instruction would also include a description of the primary spatial schema, or a proto scene associated with a particular preposition. In the model below, the two primary spatial schemas are referred to as container and surface, which provide the learners with an image of the conceptualisation of space in English and Slovene. Secondly, as we have seen above, languages differ in the way they conceptualise space, which is often the reason for the frequent occurrence of negative transfer in the use of prepositional phrases. To account for this difference, a CL-based approach would make explicit reference to the ways the two languages differ in the conceptualisation of space, giving explicit examples (e.g. Eng. in the garden, Slo. *on the garden). Thirdly, where possible, related uses of prepositions should be pointed out. In other words, rather than a list of unrelated items, learners are presented with a general schema that underlies all the uses of a preposition and other related uses.

\section{CL-Based Approach}

1. Prepositions of space describe where one person or thing is in relation to another. "In" is usually used when a thing or person is placed in a container-like place, but we can also use it to talk about a place as a general area, such as a town or a country. "On" is usually used when a thing or person is placed on, or is in contact with, a flat surface. We can also use "on" when we talk about a place in relation to a line, such as a road or a river. In most cases, Slovene and English use "in" and "on" for the same space relations.

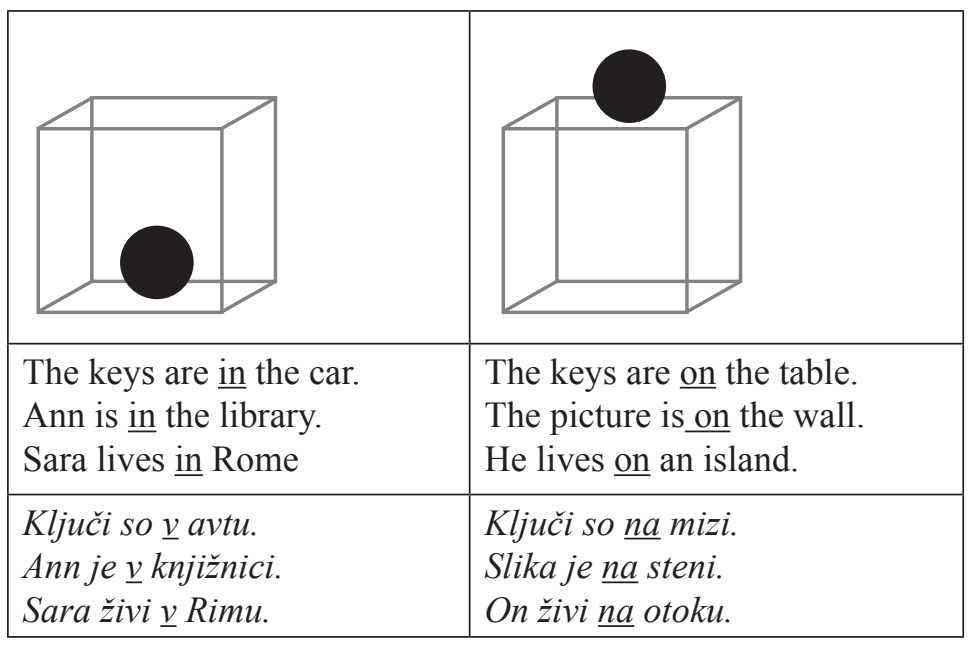


2. However, there are several cases in which there is a mismatch between English and Slovene. In the examples below, English sees the place as a container, whereas Slovene sees it as a surface.

\begin{tabular}{|l|}
\hline $\begin{array}{l}\text { in the garden } \\
\text { in the field } \\
\text { in the picture } \\
\text { in the world } \\
\text { in the square (of a town) } \\
\text { in the sky } \\
\text { in the middle (of the road) }\end{array}$ \\
$\begin{array}{l}\text { na vrtu } \\
\text { na polju } \\
\text { na sliki } \\
\text { na svetu } \\
\text { na trgu } \\
\text { na srebu }\end{array}$ \\
\hline
\end{tabular}

3. In English, the preposition "at" is also frequently used for basic space relations. It is used to talk about a general vicinity. The equivalent of "at", in Slovene, is usually $v$, na or pri.

\begin{tabular}{|l|l|}
\hline at the baker's & v pekarni \\
at the office & v pisarni \\
at school & v šoli \\
at a party & na zabavi \\
at a bus stop & na postaji \\
at the airport & na letališč \\
at the counter & na/pri blagajni \\
at 5 Maryland Street & na ulici Maryland Street 5 \\
at the door & na vratih \\
at Peter's (house) & pri Petru \\
\hline
\end{tabular}

\subsection{Learners' Response to CL-Based Teaching Material}

Having developed the CL-based instruction model on the basic uses of the prepositions in question, I was interested in observing the response of learners to the proposed approach. For this purpose, a small-scale study was conducted with first-year students at the Faculty of Education. The sample $(\mathrm{n}=87)$ consisted of two groups (the first group consisted of 45 students, the second of 42) which were each given a different set of instructions on the use of the locative prepositions in, on and at in English. The first group was given a CL-based instruction, the second the standard model. They were instructed to read the explanations and return the papers after 10 minutes. Then, they were given a 
fill-in-the-blanks test (with 32 blank spaces) which they were required to complete with missing prepositions. A select number of examples (both in the instructions and the test) included preposition uses which do not match in the two languages and in which a high occurrence of negative transfer is predicted for Slovene learners of English. For example, negative transfer was predicted for the use of the preposition in the prepositional phrase at the bus stop, in which Slovene usually uses the preposition on. This was confirmed by the results of the test which showed that, of the 87 students, 15 selected the wrong preposition in the test, and the majority of these (13) used the preposition on.

The analysis which followed focused on the results of the test for ten prepositional phrases in which prepositions in English and Slovene do not match: in the field, in the garden, in the middle, in the (town) square, in the sky, at the party, at the bus stop, at the counter, at 56 Randal Rd. As we can see from Graph 1, the highest negative transfer occurred with the phrases in the square and at 56 Randal Rd., while both groups were rather successful in using the right preposition in in the garden, in the middle, at the party, at the bus stop and at the airport. We can also see that the group which was given CL-based instruction on prepositions was more successful than the group with standard instruction in 8 out of 10 examples.

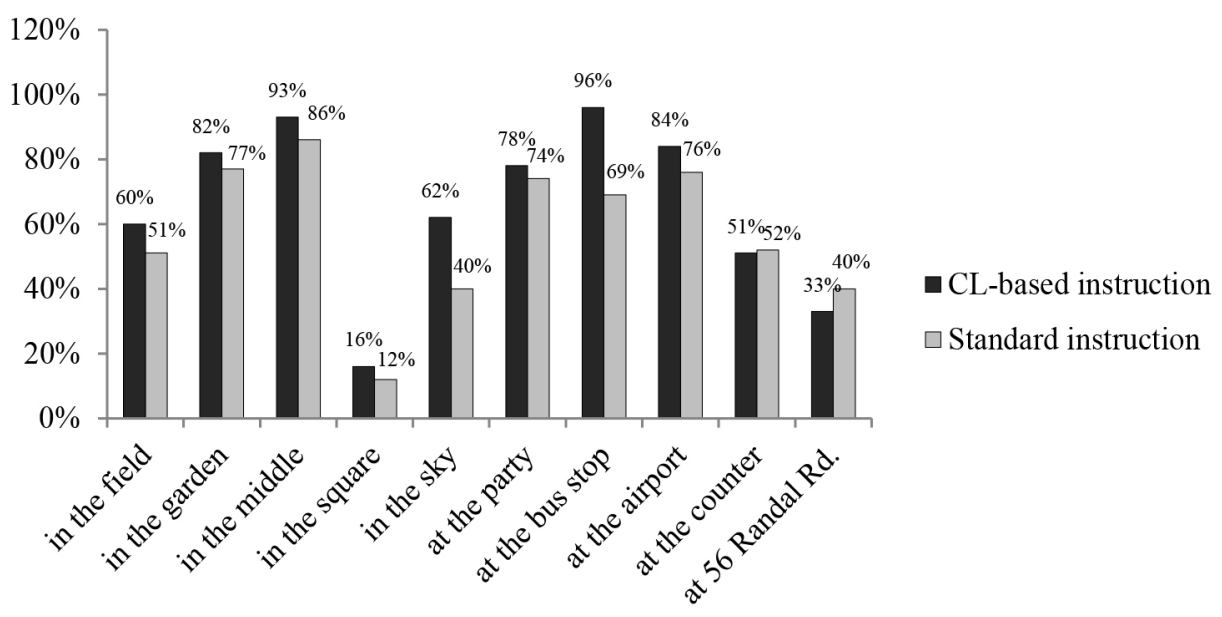

Graph 1: Test results following a CL-based vs. standard instruction (in percent)

In addition to this analysis, a discussion was conducted with a focus group of nine students aimed at identifying their opinion about the two sets of instruction. The majority of the students reported that they found the CL-based model "useful" and "interesting" but, at the same time, pointed out that the standard model was "clearer" and "easier to understand". Several members of the focus group declared that the standard instruction was easier to follow, because it was shorter. Three students added that the standard model was closer to what they had been used to and was therefore "more familiar". However, all the students agreed that it was especially useful to look at the comparison between English and Slovene in the CL-based model. 


\subsection{Discussion}

One of the main aims of the present study was to investigate to what extent learners would be able to make sense of grammatical instruction which contains some basic elements of the cognitive linguistics approach. The results above indicate that learners were able to follow the CL-based instructions and to make accurate interpretations of the explanations for the use of the prepositions in, on and at. This was especially important considering the discussion with the focus group in which the participants reported that they were more comfortable with the standard instruction but said that they would nevertheless be able to interpret the CL-based explanations.

The group which was given the CL-based instruction was generally more successful in selecting the correct preposition compared to the group which received the standard instruction. Examples with the English preposition on were not included in the analysis, since they presented no difficulty for the Slovene students. This confirms Sicherl's (2007) conclusions discussed above. The preposition on was included in the two sets of instruction and the examples for two main reasons: first, because learner's grammars usually discuss on, together with in and at as referring to basic spatial configuration; and second, because it is frequently used by Slovene learners instead of in or at as a result of negative transfer. This said, however, it is necessary to point out that the problem of negative transfer is not the same for all mismatched prepositions, since many of them are used in familiar word patterns or chunks which, when repeated across learning experiences, are easier and better remembered (Ellis 2003: 73).

Clearly, more research needs to be done to elaborate and prove the effectiveness of this approach. While a fully-fledged experiment would have to be carried out in order to test the efficacy of the method, I would like to argue that there are several reasons for further exploring the potential of applying CL insights to pedagogical grammar. First of all, a CL-based approach is able to deal with errors due to negative transfer by focusing on the mismatch between L1 and L2 in the organisation of various conceptual fields. Explicit comparisons can help learners determine and deal with negative transfer (Odlin 1989: 33), which gives learners the possibility to grasp the relationship between the two languages involved and reflect on their own learning and acquisition process. In addition, negative transfer implies also positive transfer, which is the facilitating influence exerted by the many similarities between the native and the target languages (idem.: 26). In this context, Benson (2002) argues that teachers can raise consciousness of the differences between L1 and L2 by focusing on particular points in an explicit way and eliciting awareness. Secondly, by exposing learners to a systematic account of conventional meanings related to a particular preposition, we are able to cut down on the amount of arbitrariness, and therefore reduce the need for rote learning and memorization.

\section{CONCLUSION}

Several attempts have been made to translate the theoretical implications from the area of CL into pedagogical practice. However, there are still significant challenges to be addressed and studied. With a view to narrowing the gap between theory and practice, this article has discussed some of the ways in which CL findings can be practically 
used for SLT purposes. We have seen that prepositions have traditionally been seen as unpredictable, implying that the best way to learn them would be through rote learning. A CL-based approach argues that the distinct meanings associated with a particular preposition are systematically related in principled ways, which may have important ramifications for second language instruction. However, it is clear that more needs to be done in order for the theory to be translated into effective teaching practice. First of all, for a more comprehensive inclusion of CL insights in the area of second language teaching and learning, CL research should focus more on the contrastive aspects between the native and target language, thus helping to determine the potential negative transfer. This would entail a language-pair-specific approach to SL teaching. Secondly, more research needs to be done on conducting systematic teaching and learning interventions using experimental research methods. And finally, one of the major challenges of a CL-based teaching approach is to develop accessible, learner-friendly strategies and materials aimed at facilitating the learning and acquisition process.

\section{References}

ACHARD, Michel/Susanne NIEMEIER (eds) (2004) Cognitive linguistics, second language acquisition, and foreign language teaching (Vol. 18). Berlin/New York: Walter de Gruyter.

BENSON, Cathy (2002) “Transfer/Cross-linguistic influence." ELT Journal 56/1, 68-70. BRATOŽ, Silva/Alenka KOCBEK (2013) "Resurrecting Translation in SLT: A Focus on Young Learners.” In: D. Tsagari/G. Floros (eds), Translation in Language Teaching and Assessment. Newcastle upon Tyne: Cambridge Scholars Publishing, 135-153.

CELCE-MURCIA, Marianne/Diane LARSEN-FREEMAN (1998) The Grammar Book: An ESL/EFL Teacher's Course. Rowley, Mass.: Newbury House.

Common European Framework of Reference for Languages: Learning, Teaching, Assessment (2001). Cambridge: Cambridge University Press.

ELLIS, Nick C. (2003) "Constructions, chunking, and connectionism: The emergence of second language structure." In: C. J. Doughty/M. H. Long (eds), The handbook of second language acquisition. Oxford: Blackwell, 63-103.

EVANS, Vyvyan/Andrea TYLER (2005) "Applying Cognitive Linguistics to Pedagogical Grammar: The English Prepositions of Verticality." Revista Brasileira de Lingüística Aplicada 5/2, 11-42.

KOCBEK, Alenka (2013) "Translation science as an aid to second language teaching." In: A. Akbarov/D. Larsen-Freeman (eds), Teaching, acquiring and applying intercultural linguistic competence: proceedings book. Sarajevo: International Burch University Publication, 63-72.

LAKOFF, George (1987) Women, fire, and dangerous things: What categories reveal about the mind. Chicago: University of Chicago.

LINDSTROMBERG, Seth (1996) "Prepositions: Meaning and method." ELT Journal 50/3, 225-236.

LITTLEMORE, Janette (2009) Applying cognitive linguistics to second language learning and teaching. Basingstoke: Palgrave Macmillan. 
LORINCZ, Kristen/Rebekah GORDON (2013) "Difficulties in Learning Prepositions and Possible Solutions." Linguistic Portfolios 1/1, 14.

MUELLER, Charles M. (2011) "English learners' knowledge of prepositions: Collocational knowledge or knowledge based on meaning?" System 39/4, 480-490.

ODLIN, Terence (1989) Language transfer: Cross-linguistic influence in language learning. Cambridge: Cambridge University Press.

PIŽORN, Karmen/Mihaela BRUMEN (2008) "Evropske smernice za učenje tujih jezikov na predšolski in razredni stopnji osnovne šole." Revija za elementarno izobraževanje 1/3-4, 139-146.

ROHLFING, Katharina J. (2001) "No preposition required. The role of prepositions for the understanding of spatial relations in language acquisition." In: M. Pütz/S. Niemeier/R. Dirven (eds), Applied cognitive linguistics I: theory and language acquisition. Berlin: Mounton de Gruyter, 230-247.

SICHERL, Eva (2007) "Radialni model angleškega predloga on v odnosu do slovenskega predloga na." Slavistična revija 55/3, 559-579.

TYLER, Andrea/Charles MUELLER/Vu HO (2011) "Applying cognitive linguistics to learning the semantics of English to, for and at: An experimental investigation." Vigo International Journal of Applied Linguistics 8, 180-205.

\section{Summary \\ TEACHING ENGLISH LOCATIVE PREPOSITIONS: A COGNITIVE PERSPECTIVE}

Prepositions are notoriously hard to learn, and frequently subject to negative transfer. In addition, prepositional meanings are commonly extended from the spatial to abstract domains and are, as a consequence, often unpredictable and arbitrary. Traditional approaches to second language preposition teaching have, therefore, suggested that the best way to learn prepositions would be through rote learning. On the other hand, a cognitive linguistics approach argues that the multiple uses of prepositions can be seen as related in systematic ways. Several pedagogical implications of applying cognitive linguistics findings in second language teaching and learning will be discussed, suggesting ways of translating theory into practical consideration and effective teaching materials. The second part of the article presents an instructional model for teaching the locative prepositions in, on and at from a cognitive perspective, and discusses the results of a study conducted to observe the learners' response to instruction, based on cognitive linguistics findings. In addition, the benefits of focusing on the cross-linguistic differences between the native and target language, in an explicit and systematic way, will be discussed. In this context, reference will be made to several insights and ideas promoted by the CEFR. The article will end by considering some suggestions and ideas for future research.

Keywords: cognitive linguistics, prepositions, cross-linguistic transfer, foreign language teaching, CEFR. 


\section{Povzetek \\ POUČEVANJE ANGLEŠKIH PREDLOGOV V FUNKCIJI IZRAŽANJA KRAJEVNO-PROSTORSKIH RAZMERIJ: KOGNITIVNI POGLED}

$\mathrm{Na}$ učenje predlogov $\mathrm{v}$ tujem jeziku pogosto vpliva negativni transfer iz učenčevega maternega jezika. Poleg tega se pomeni, povezani z določenim predlogom, pogosto razširijo s prostorskih na abstraktne domene, zaradi česar postanejo nepredvidljivi in naključni. Tradicionalni pristopi k poučevanju tujega jezika zato kot strategijo za učenje predlogov predlagajo učenje na pamet. Po drugi stran pa pristop, ki izhaja iz kognitivnega jezikoslovja, zagovarja tezo, da so različni pomeni predlogov sistematično povezani. Članek obravnava različne vidike uporabe ugotovitev s področja kognitivnega jezikoslovja pri tujejezikovnem učenju in poučevanju s poudarkom na povezovanju teorije s praktičnimi rešitvami in učinkovitimi učnimi gradivi. V drugem delu članka je prikazan model učne razlage rabe angleških predlogov in, on in at s kognitivnega vidika. Predstavljeni so tudi rezultati raziskave, v kateri smo preverjali odziv učencev tujega jezika na učno razlago, ki temelji na ugotovitvah kognitivnega jezikoslovja. Poudarjene so prednosti eksplicitnega in sistematičnega upoštevanja medjezikovnih razlik pri poučevanju tujega jezika, pri čemer se članek navezuje tudi na vpoglede in načela Skupnega evropskega jezikovnega okvira. V zaključku so podani predlogi in pobude za nadaljnje raziskovanje na tem področju.

Ključne besede: kognitivno jezikoslovje, predlogi, medjezikovni transfer, poučevanje tujega jezika, SEJO. 